\title{
Biochemical Responses of Two Species of Eucalyptus Exposed to Aluminium Toxicity: Oxidative Stress and Antioxidant Metabolism
}

\author{
Udson de Oliveira BARROS JUNIOR ${ }^{1}$, Michael Douglas Roque LIMA ${ }^{1}$, Maria
} Antonia Machado BARBOSA ${ }^{2}$, Bruno Lemos BATISTA ${ }^{3}$, Allan Klynger da Silva LOBATO ${ }^{1 *}$

\author{
${ }^{I}$ NúdleodePesquisa Vegetal Básica A Aplicada,UniversidadeFederal Ruralda Amazônia, Paragominas,_Brazila; udson_engflorestal@outlook.com; lima florestal@outlook.com; \\ allanllobato@yahoo.com.br(*orrespondingauthor) \\ ${ }^{2}$ Departamento de Biologia Vegetal, Universidade Federal deViçosa, Viçosa, Brazil;suzymbarbosa@hotmail.com \\ ${ }^{3}$ Centrode Ciências Naturaise Humanas, Universidade Federaldo ABC, Santo André,SäoPaulo, Brazilibrlemosbr@yahoo.com.br
}

\begin{abstract}
In response to oxidative damage resulting from overproduction of reactive oxygen species, plants have developed complex and efficient antioxidant machinery. The aims of this research were to measure composts used as stress indicators, quantifying non-enzymatic compounds and activities of antioxidant enzymes, and to explain probable differences between two species of the gender Eucalyptus exposed to low and high aluminium. The experiment employed a factorial that was entirely randomised, with two species (Eucalyptus platyphylla and E. grandis) combined with aluminium concentrations (and 0.08 and $1.60 \mathrm{mM} \mathrm{Al}$, which are described as low and high $\mathrm{Al}$, respectively). This study revealed that the E. platyphylla presented intense modifications on malondialdehyde and electrolyte leakage in leaf and root, being also detected increases to oxidized glutathione, reduced glutathione and total glutathione. In addition, E. platyphylla had strong accumulations linked to superoxide and hydrogen peroxide, while E. grandis were detected minor alterations to both tissues. In relation to superoxide dismutase, catalase, ascorbate peroxidase and peroxidase were showed similar behaviours, with higher activities in $E$. grandis, if compared to E. platyphylla. Therefore, is possible to conclude that E. grandis is more tolerant to aluminium due to minor production of reactive oxygen species and decreased alterations on stress indicators. Concomitantly, the antioxidant enzymes effectively contribute to reduce the oxidative stress generated in root and leaf of $E$. grandis exposed to high aluminium.
\end{abstract}

Keywords: antioxidant enzymes, catalase, element toxic, hydrogen peroxide, reactive oxygen species, tolerance mechanism

\section{Introduction}

One of the limiting factors in the growth and development of plants is the soil acidity associated with aluminium (Al) toxicity (Haynes and Mokolobate, 2001). Al is found in trivalent form in acid soils and is soluble and toxic to plants, corroborating the idea that the solubility of this element is highly dependent on the $\mathrm{pH}$ (Hoekenga et al., 2003). Under acidic soil conditions at $\mathrm{pH}<5.5$, the $\mathrm{H}^{+}$acts by releasing $\mathrm{Al}_{3}{ }^{+}$ions from minerals that were previously attracted by the negative charges of the clay particles (Delhaize and Ryan 1995; Leite et al., 2011). In other words, the decreased soil $\mathrm{pH}$ induces an increase in the $\mathrm{Al}$ activity in soil and consequently increases $\mathrm{Al}$ solubility, with negative effects linked to oxidative stress in plants (Nolla and Anghinoni, 2004).
Reactive oxygen species (ROS), including superoxide $\left(\mathrm{O}_{2}^{-}\right)$, hydrogen peroxide $\left(\mathrm{H}_{2} \mathrm{O}_{2}\right)$ and hydroxyl radicals $\left(\mathrm{OH}^{-}\right)$, are highly reactive biomolecules and toxic to plants (Blokhina et al., 2003; Edreva, 2005; Barbosa et al., 2014). They are produced in balanced concentrations within the cellular compartments, such as chloroplasts, mitochondria, peroxisomes and apoplast (Moller, 2001; Asada, 2006; Sharma et al., 2012), as a product of the photosynthesis and respiration processes (Asada, 1999; Pitzschke et al., 2006; Miller et al., 2010). The Al toxicity often induces overproduction and accumulation of ROS (Yamamoto et al., 2003; Chen et al., 2010; Li et al., 2011). Excessive ROS generation within cells causes severe oxidative damage, such as lipid peroxidation of the cell membrane, denaturation of proteins and structural damage of DNA (Scandalios, 1993; Mittler, 2002; Meriga, 2004; Achary et al., 2008). 
108

In addition, the ROS compromise also the functioning of the cell organelles and inhibit respiration and cell growth (Yamamoto $e t$ al., 2002; Qin et al., 2010).

In response to oxidative damage resulting from overproduction of ROS, plants have developed complex and efficient antioxidant machinery (Giannakoula et al., 2010; Pereira et al., 2014), which is composed of non-enzymatic and enzymatic factors, both used for the elimination of ROS (Mukhopadyay et al., 2012; Pereira et al., 2015). The ascorbic acid (AsA) and glutathione (GSH) compounds are considered the major non-enzymatic, and are fundamental during oxidative stress (Gill and Tuteja, 2010; Wang et al., 2011). Both are responsible to protect cells from oxidative damages and contribute to adequate detoxification process promoted by the antioxidant enzymes (Gratão et al., 2005; El-Beltagi and Mohamed, 2013).

In relation to antioxidant enzymes, there are the superoxide dismutase (SOD), catalase (CAT), ascorbate peroxidase (APX) and guaiacol peroxidase (GPX) (Coscolin et al., 2011). The SOD acts as the first enzyme of the antioxidant machinery, converting the excess $\mathrm{O}_{2}^{-}$to $\mathrm{H}_{2} \mathrm{O}_{2}$ and $\mathrm{O}_{2}$ (Alscher et al., 2002). Similarly, the enzymes CAT, APX and GPX dismutate the $\mathrm{H}_{2} \mathrm{O}_{2}$ excess, transforming it in $\mathrm{H}_{2} \mathrm{O}$ and $\mathrm{O}_{2}$ (Zhu et al., 2010). For this, the CAT performs the dismutation directly, while APX and GPX use AsA and GSH as substrates (Gratão et al., 2005; El-Beltagi and Mohamed, 2013).

Our hypothesis is that Eucalyptus platyphylla and Eucalyptus grandis must present different responses linked to tolerance mechanism under aluminium toxicity, verifying the ROS accumulation and a probable contribution of antioxidant enzymes. Based in this overview, the aims of this research were to measure composts used as stress indicators, quantifying nonenzymatic compounds and activities of antioxidant enzymes, and to explain probable differences between two species of the gender Eucalyptus exposed to low and high aluminium.

\section{Materials and Methods}

\section{Location and growth conditions}

This experiment was performed at the Campus of Paragominas of the Universidade Federal Rural da Amazônia, Paragominas, Brazil ( $2^{\circ} 55^{\prime} \mathrm{S}$ and $\left.47^{\circ} 34^{\prime} \mathrm{W}\right)$. The study was conducted in a greenhouse without environmental controls, and the minimum, maximum, and median temperatures were $24^{\circ} \mathrm{C}$, $33^{\circ} \mathrm{C}$, and $27.2^{\circ} \mathrm{C}$, respectively. The relative humidity during the experimental period varied between $68 \%$ and $87 \%$, and the photoperiod was set to $12 \mathrm{~h}$ of light. During the measurement period $(12: 00 \mathrm{~h})$, the amount of photosynthetically active radiation varied between 572 and $1,564 \mu \mathrm{mol} \mathrm{m}^{-2} \mathrm{~s}^{-1}$.

\section{Plants, containers and acclimation}

Sixty-day-old seedlings of Eucalyptus platyphylla and Eucalyptus grandis from DACKO presenting similar aspects and sizes were selected and placed in 1.2-L containers $(0.15 \mathrm{~m}$ in height and $0.10 \mathrm{~m}$ in diameter) filled with substrate mix composed of sand and vermiculite in a 2:1 proportion. For semi-hydroponic cultivation, the previously described containers were equipped with one hole in the bottom and covered with mesh to keep the substrate, and solution absorption by capillarity, being misplaced into the other containers $(0.15 \mathrm{~m}$ in height and $0.15 \mathrm{~m}$ in diameter) containing $500 \mathrm{~mL}$ of nutritive Hoagland and Arnon (1950) solution adjusted to the nutritional exigencies of this species. The ionic force started at $25 \%$, and it was modified to 50 and $100 \%$ at regular intervals of three days. After these periods, the nutritive solution remained with the total ionic force. Subsequently, the 75-day-old young plants were submitted to low and high aluminium $(\mathrm{Al})$ concentrations.

\section{Experimentaldesign}

The experiment employed a factorial that was entirely randomised, with two species (E. platyphylla and E. grandis) combined with aluminium concentrations (and 0.08 and 1.60 $\mathrm{mM} \mathrm{Al}$, which are described as low and high $\mathrm{Al}$, respectively). The experiment was assembled with five replicates for a total of 20 experimental units, with one plant in each unit.

\section{Plant conduction and aluminium treatments}

During plant conduction, one young plant was placed in each pot. The treatments received macronutrients and micronutrients from the nutritive solution containing $6 \mathrm{mM} \mathrm{KNO}_{3}, 5 \mathrm{mM}$ $\mathrm{Ca}\left(\mathrm{NO}_{3}\right)_{2} \cdot 4 \mathrm{H}_{2} \mathrm{O}, 2 \mathrm{mM} \mathrm{NH} \mathrm{H}_{2} \mathrm{PO}_{4}, 1 \mathrm{mM} \mathrm{MgSO} \cdot 7 \mathrm{H}_{2} \mathrm{O}$, $62.50 \mu \mathrm{M} \mathrm{KCl}, 31.25 \mu \mathrm{M} \mathrm{H}_{3} \mathrm{BO}_{3}, 2.50 \mu \mathrm{M} \mathrm{MnSO}_{4} \cdot \mathrm{H}_{2} \mathrm{O}, 2.50$ $\mu \mathrm{M} \quad \mathrm{ZnSO}_{4} \cdot 7 \mathrm{H}_{2} \mathrm{O}, \quad 0.63 \mu \mathrm{M} \quad \mathrm{CuSO}_{4} \cdot 5 \mathrm{H}_{2} \mathrm{O}, 0.63 \mu \mathrm{M}$ $\mathrm{NaMoO}_{4} \cdot 5 \mathrm{H}_{2} \mathrm{O}$, and $200.0 \mu \mathrm{M} \mathrm{NaEDTAFe} \cdot 3 \mathrm{H}_{2} \mathrm{O}$. To simulate low and high $\mathrm{Al}$ concentrations, $\mathrm{AlCl}_{3}$ was used at concentrations of 0.08 and $1.60 \mathrm{mM} \mathrm{Al}$, respectively. Two Al concentrations were applied to the young plants for 30 days. During the cultivation, the solutions were changed at 07:00 h over 5-day intervals and their $\mathrm{pH}$ values were adjusted to 5.5 and 4.2 to low and high $\mathrm{Al}$ concentrations, respectively, by using $\mathrm{HCl}$ or $\mathrm{NaOH}$. All plants were physiologically and morphologically measured on the $30^{\text {th }}$ day after the treatments, and the leaf tissue was harvested for nutritional and biochemical analysis.

\section{Extracting and determining of Al in leaves}

Samples containing $100 \mathrm{mg}$ of dry leaf matter were predigested with $2 \mathrm{~mL}$ of concentrated $\mathrm{HNO}_{3}$ (sub-boiling) for $48 \mathrm{~h}$ in $50 \mathrm{~mL}$ conic tubes (BD, model Falcon). Afterwards, $4 \mathrm{~mL}$ of $\mathrm{H}_{2} \mathrm{O}_{2}(30 \% \mathrm{v} / \mathrm{v}$, Fluka) $+4 \mathrm{~mL}$ of ultra-pure water (Milli-Q) were added and the mixture was transferred to a PFA digestion vessel and digested in a microwave system (Milestone, model ETHOS 1600) according to the following heating regimen: i) $100{ }^{\circ} \mathrm{C}$ during $20 \mathrm{~min}$; ii) $150{ }^{\circ} \mathrm{C}$ during $20 \mathrm{~min}$; iii) $230{ }^{\circ} \mathrm{C}$ for $10 \mathrm{~min}$; and iv) left to cool. The volume was then filled up to $50 \mathrm{~mL}$ with ultra-pure water and rhodium was added as an internal standard $\left(10 \mu \mathrm{L} \mathrm{L}^{-1}\right)$. The analyses were performed by using an inductively coupled plasma mass spectrometer (ICP-MS Perkin Elmer, model ELANDRC II).

\section{Electrolyte leakage}

Electrolyte leakage was measured according to the method described by Gong et al. (1998) with minor modifications. Fresh leaves and roots $(200 \mathrm{mg})$ were cut into pieces with a length of 1 $\mathrm{cm}$ and were placed in containers containing $8 \mathrm{~mL}$ of distilled deionised water. The containers were incubated in a water bath at $40{ }^{\circ} \mathrm{C}$ for $30 \mathrm{~min}$, and the initial electrical conductivity of the medium $\left(\mathrm{EC}_{1}\right)$ was measured. The samples were boiled at $95^{\circ} \mathrm{C}$ for $20 \mathrm{~min}$ to release the electrolytes. After the samples were cooled, the final electrical conductivity $\left(\mathrm{EC}_{2}\right)$ was measured (Gong et al., 1998). The percentage of electrolyte leakage was calculated using the formula $\mathrm{EL}(\%)=\left(\mathrm{EC}_{1} / \mathrm{EC}_{2}\right) \times 100$. 


\section{Extraction of non-enzymatic compounds}

Non-enzymatic compounds $\left(\mathrm{H}_{2} \mathrm{O}_{2}, \mathrm{MDA}, \mathrm{GSSG}\right.$ and total GSH) were extracted as described by Wu et al. (2006). Briefly, an extraction mixture was prepared by homogenising $500 \mathrm{mg}$ of fresh leaf matter in $5 \mathrm{~mL}$ of $5 \%(\mathrm{w} / \mathrm{v})$ trichloroacetic acid. Subsequently, the samples were centrifuged at $15,000 \mathrm{x} g$ for 15 $\min$ at $3^{\circ} \mathrm{C}$, and the supernatant was collected.

\section{Hydrogen peroxide determination}

For $\mathrm{H}_{2} \mathrm{O}_{2}$ detection, $200 \mu \mathrm{L}$ of supernatant and $1800 \mu \mathrm{L}$ of reaction mixture $(2.5 \mathrm{mM}$ potassium phosphate buffer $[\mathrm{pH} 7.0]$ and $500 \mathrm{mM}$ potassium iodide) were mixed, and the absorbance was measured at $390 \mathrm{~nm}$ (Velikova et al., 2000).

\section{Malondialdehyde quantification}

MDA was determined by mixing $500 \mu \mathrm{L}$ of supernatant with $1,000 \mu \mathrm{L}$ of the reaction mixture, which contained $0.5 \%$ (w/v) thiobarbituric acid in $20 \%$ trichloroacetic acid. The mixture was incubated in boiling water at $95^{\circ} \mathrm{C}$ for $20 \mathrm{~min}$, and the reaction was terminated by placing the reaction container in an ice bath. The samples were centrifuged at $10,000 \times g$ for 10 $\mathrm{min}$, and the absorbance was measured at $532 \mathrm{~nm}$. The amount of non-specific absorption at $600 \mathrm{~nm}$ was subtracted from the absorbance data. The amount of MDA-TBA complex (red pigment) was calculated based on the method of Cakmak and Horst (1991) with minor modifications, using an extinction coefficient of $155 \mathrm{mM}^{-1} \mathrm{~cm}^{-1}$.

\section{Content glutathione estimations}

For total GSH detection, $200 \mu \mathrm{L}$ of supernatant, $1,800 \mu \mathrm{L}$ of reaction mixture (containing $100 \mathrm{mM}$ phosphate buffer $[\mathrm{pH}$ 7.6] and 0.60 mM 2-nitrobenzoic acid) were combined, and the absorbance was measured at $412 \mathrm{~nm}$ (Wu et al., 2006).

To GSSG determination, $195 \mu \mathrm{L}$ of neutralized extract was incubated with $2.6 \mu \mathrm{L}$ of 2-vinylpyridine for $1 \mathrm{~h}$ at $25^{\circ} \mathrm{C}$. Subsequently, were added $0.25 \mathrm{mM}$ NADPH, $0.42 \mathrm{mM}$ DTNB [pH 7.6], and 1 unit of GR, being the absorbance was measured at $412 \mathrm{~nm}$ (Griffith, 1980). The concentration of reduced glutathione $(\mathrm{GSH})$ was calculated as the difference between total GSH and GSSG.

\section{Extraction of antioxidant enzymes and soluble proteins}

Superoxide, soluble proteins and antioxidant enzymes (SOD, CAT, APX, and GPX) and were extracted from leaf and root tissues as per the method of Badawi et al. (2004). The extraction mixture was prepared by homogenizing $500 \mathrm{mg}$ of fresh matter in $5 \mathrm{ml}$ of extraction buffer, consisting of $50 \mathrm{mM}$ phosphate buffer (pH 7.6), $1.0 \mathrm{mM}$ ascorbate and $1.0 \mathrm{mM}$ EDTA. Samples were centrifuged at $14,000 \times g$ for 4 min at 3 ${ }^{\circ} \mathrm{C}$, and the supernatant was collected. Quantification of the total soluble proteins was performed using the method described by Bradford (1976). The absorbance was measured at $595 \mathrm{~nm}$, using bovine albumin as standard.

\section{Superoxide determination}

The $\mathrm{O}_{2}^{-}$determination, $1 \mathrm{ml}$ of extract was incubated with $30 \mathrm{mM}$ phosphate buffer $[\mathrm{pH} \quad 7.6]$ and $0.51 \mathrm{mM}$ hydroxylamine hydrochloride for $20 \mathrm{~min}$ at $25^{\circ} \mathrm{C}$. Subsequently, were added $17 \mathrm{mM}$ sulphanilamide and $7 \mathrm{mM} \alpha$-naphthylamine to incubation mixture for $20 \mathrm{~min}$ at $25^{\circ} \mathrm{C}$. After reaction, ethyl ether in the same volume was added and centrifuged at 3,000 $\times g$ for $5 \mathrm{~min}$. The absorbance was measured at $530 \mathrm{~nm}$ (Elstner and Heupel, 1976).

\section{Superoxide dismutase assay}

For SOD assay (EC 1.15.1.1), $2.8 \mathrm{ml}$ of reaction mixture containing $50 \mathrm{mM}$ phosphate buffer (pH 7.6),0.1 mM EDTA, $13 \mathrm{mM}$ methionine ( $\mathrm{pH}$ 7.6), $75 \mu \mathrm{M}$ NBT, $4 \mu \mathrm{M}$ riboflavin were mixed with $0.2 \mathrm{ml}$ of supernatant. The absorbance was then measured at $560 \mathrm{~nm}$ (Giannopolitis and Ries, 1977).

Catalase assay

For CAT assay (EC 1.11.1.6), $0.2 \mathrm{ml}$ of supernatant and 1.8 $\mathrm{ml}$ of reaction mixture containing $50 \mathrm{mM}$ phosphate buffer $(\mathrm{pH}$ 7.0 ) and $12.5 \mathrm{mM}$ hydrogen peroxide were mixed, and the absorbance was measured at $240 \mathrm{~nm}$ (Havir and McHale, 1987).

\section{Ascorbateperoxidase assay}

For APX assay (EC 1.11.1.11), $1.8 \mathrm{ml}$ of reaction mixture containing $50 \mathrm{mM}$ phosphate buffer $(\mathrm{pH} 7.0), 0.5 \mathrm{mM}$ ascorbate, $0.1 \mathrm{mM}$ EDTA, and $1.0 \mathrm{mM}$ hydrogen peroxide were mixed with $0.2 \mathrm{ml}$ of supernatant, and the absorbance was measured at $290 \mathrm{~nm}$ (Nakano and Asada 1981).

\section{Peroxidase assay}

For GPX assay (EC 1.11.1.7), $1.78 \mathrm{ml}$ of reaction mixture containing $50 \mathrm{mM}$ phosphate buffer ( $\mathrm{pH} \mathrm{7.0)}$ and $0.05 \%$ guaiacol was mixed with $0.2 \mathrm{ml}$ of supernatant, followed by addition of $20 \mu \mathrm{L}$ of $10 \mathrm{mM}$ hydrogen peroxide. The absorbance was then measured at $470 \mathrm{~nm}$ (Cakmak and Marschner 1992).

\section{Data analysis}

The data were subjected to an analysis of variance, and significant differences between the means were determined by Scott-Knott test at a probability level of 5\% (Steel et al., 2006). Standard deviations were calculated for each treatment. The statistical analyses were performed with Assistat software.

\section{Results}

Al concentration in leaf and modifications linked to $\mathrm{O}_{2}^{-}, \mathrm{SOD}$ and $\mathrm{H}_{2} \mathrm{O}_{2}$

Treating with high $\mathrm{Al}$ produced significant increases in the $\mathrm{Al}$ concentrations of the leaves in both species. The E. platyphylla and E. grandis exhibited increases of 104 and 29\% (Table 1), respectively, when compared with plants of the same species under low Al.

The $\mathrm{O}_{2}$ levels in leaf and root showed significant increases of 88.2 and $275 \%$ in E. platyphylla under high $\mathrm{Al}$ (Fig. $1 \mathrm{~A}$ and B),

Table 1. Concentrations of $\mathrm{Al}$ in leaf (dry matter) of E. platyphylla and $E$. grandis exposed to low and high $\mathrm{Al}$ concentrations

\begin{tabular}{lcrcc}
\hline Specie & $\begin{array}{c}\text { Aluminium } \\
\text { concentration }\end{array}$ & \multicolumn{3}{c}{$\begin{array}{c}\text { Aluminium concentration in } \\
\text { leaf }\left(\mu \mathrm{g} \mathrm{g}^{-1} \mathrm{DM}\right)\end{array}$} \\
\hline E. platyphylla & Low & 8.9 & \pm 0.4 & $\mathrm{Ba}$ \\
E. platyphylla & High & 18.3 & \pm 0.7 & $\mathrm{Aa}$ \\
E. grandis & Low & 8.0 & \pm 0.3 & $\mathrm{Bb}$ \\
E. grandis & High & 10.4 & \pm 0.6 & $\mathrm{Ab}$ \\
\hline
\end{tabular}

Columns with different uppercase letter into species (E. platyphylla and $E$. grandis) and lowercase letter into $\mathrm{Al}$ concentrations (low and high) indicate significant differences from the Scott-Knott test $(\mathrm{P}<0.05)$. Values described corresponding to means from four repetitions and standard deviations. 
110

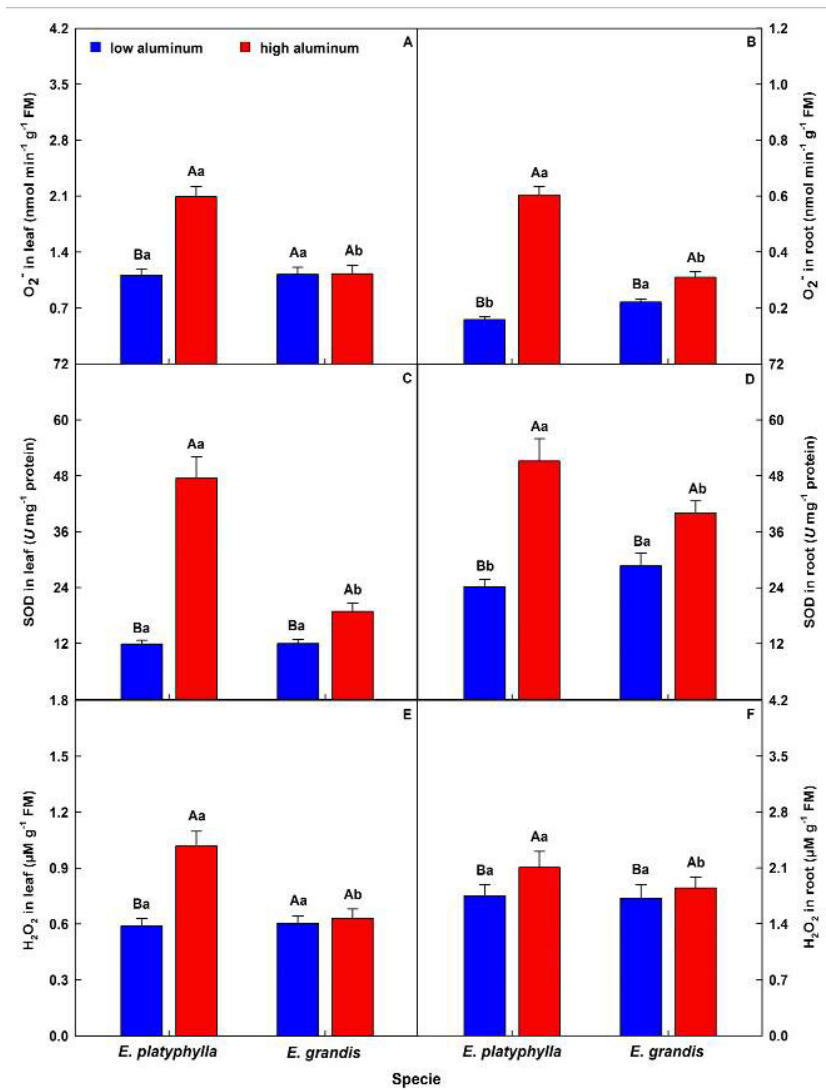

Fig. 1. Superoxide (A and B), superoxide dismutase (C and D) and hydrogen peroxide (E and $\mathrm{F}$ ) in E. platyphylla and $E$. grandis exposed to low and high $\mathrm{Al}$ concentrations. Different uppercase letter into species (E. platyphylla and E. grandis) and lowercase letter to Al concentrations (low and high) indicate significant differences from the Scott-Knott test $(\mathrm{P}<0.05)$. Columns represent the mean values from five repetitions, and bars represent the standard deviations

when compared to specie under low $\mathrm{Al}$ concentration. The SOD activities showed significant increases in leaf and root of both species being observed in leaf increases of 299 and $57 \%$ for $E$. platyphylla and E. grandis (Fig. $1 \mathrm{C}$ and D), compared to plants of the same specie with low Al. For the $\mathrm{H}_{2} \mathrm{O}_{2}$, significant increase was observed on leaf only in E. platyphylla (Fig. $1 \mathrm{E}$ ), while the root, increases were significant in both species being observed increases of 20.5 and $7.5 \%$ for E. platyphylla and E. grandis, respectively (Fig. $1 \mathrm{~F}$ ), compared with the same plants exposed to low Al concentrations.

\section{Cell damages in contrastingspecies after Al treatment}

The MDA level in leaf of $E$. platyphylla presented a significant increase of $30.1 \%$, while that $E$. grandis had only $5.2 \%$ (Fig. $2 \mathrm{~A}$ ), if compared to the same specie with low Al concentration. In root, $E$. platyphylla and E. grandis had significant increases of 55.2 and $41.6 \%$ (Fig. 2 B), comparison made in the same specie with low $\mathrm{Al}$ application. To EL, the plants treated with high Al concentrations suffered significantly increased in leaf and root tissues only for the E.platyphylla (Fig. 2C and D).

Interferences on GSSG, GSH and total GSH during Al toxicity The GSSG values were increased in both tissues of $E$.

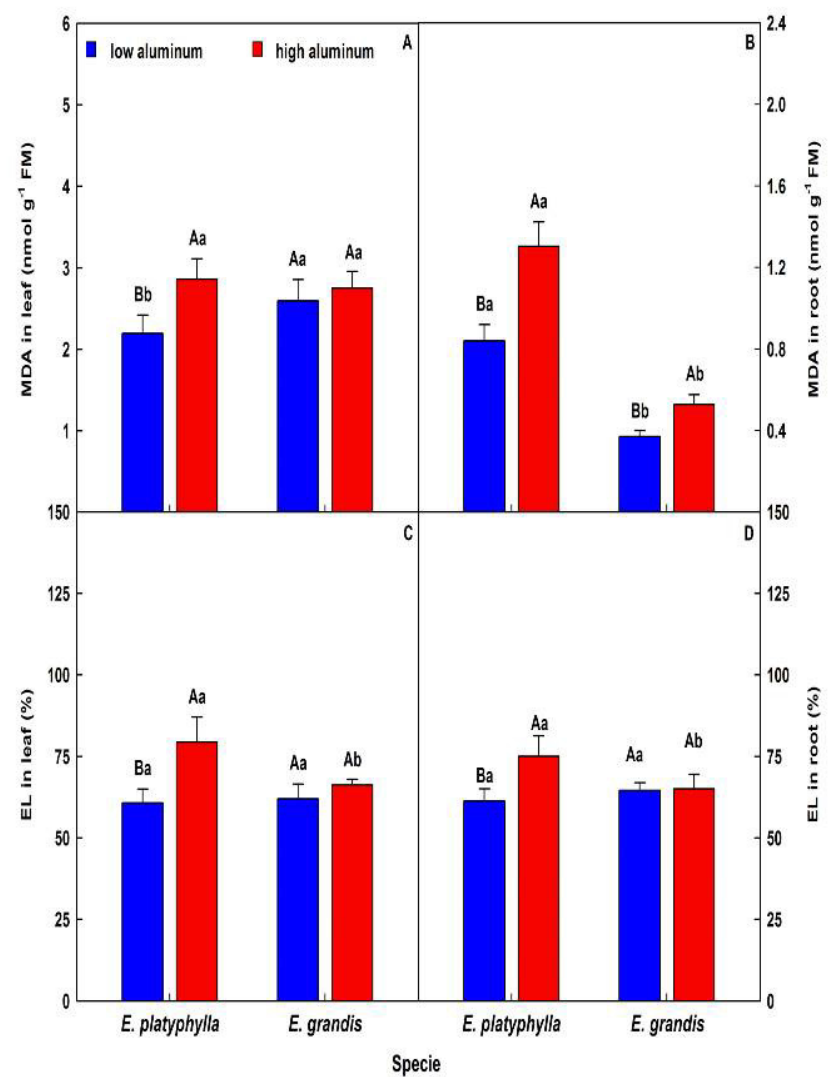

Fig. 2. Malondialdehyde (A and B) and electrolyte leakage (C and D) in E. platyphylla and E. grandis exposed to low and high $\mathrm{Al}$ concentrations. Different uppercase letter into species (E. platyphylla and E. grandis) and lowercase letter to $\mathrm{Al}$ concentrations (low and high) indicate significant differences from the Scott-Knott test $(\mathrm{P}<0.05)$. Columns represent the mean values from five repetitions, and bars represent the standard deviations

platyphylla and E. grandis subjected to high Al level (Fig. $3 \mathrm{~A}$ and B). The increase in leaf of the E. platyphylla was $498.7 \%$, while for the $E$. grandis was $122.5 \%$, if compared the same specie cultivated with low $\mathrm{Al}$ level. In relation to GSH, only the E. platyphylla showed an increase in leaf and root, under high $\mathrm{Al}$ concentration (Fig. $3 \mathrm{C}$ and D). The increases were 39.7 and $96.8 \%$ in the leaf and root, respectively, to E. platyphylla. For total GSH, the increase presented on leaf to E. platyphylla was $75 \%$, while E. grandis reached around $14 \%$ (Fig. 3E), when compared with plants grown under low $\mathrm{Al}$. To the root, the increase for the E. platyphylla was $162 \%$, and the E. grandis arrived at $45.5 \%$ ( Fig. $3 \mathrm{~F}$ ).

\section{Contribution of the antioxidant enzymes to attenuate the $A i$} stress

Plants under high $\mathrm{Al}$ application showed a significant increase in CAT activity, both in the leaves and in the roots, within two species. In E. grandis increases were 86.5 and $168 \%$ in the leaf and root, respectively (Fig. $4 \mathrm{~A}$ and B). In APX activity were obtained increases to root of $242.1 \%$ and $580.4 \%$ in E. platyphylla and $E$. grandis (Fig. $4 \mathrm{D}$ ), respectively, when compared with plants of the same specie that received low Al concentration. Plants under application high $\mathrm{Al}$ showed a significant increase in GPX activity, than leaf that to root, in both species (Fig, 4E and F). 


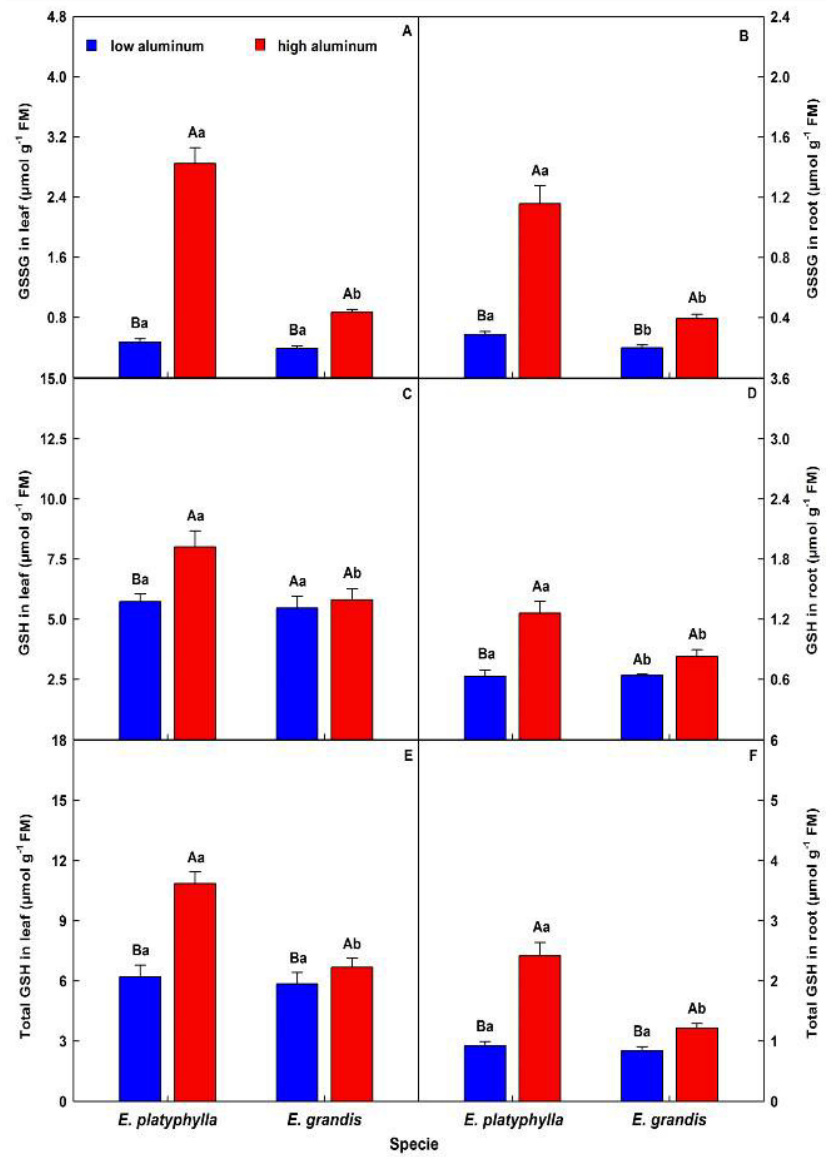

Fig. 3. Oxidized glutathione (A and $\mathrm{B}$ ), reduced glutathione (C and D) and total glutathione (E and F) in E. platyphylla and $E$. grandis exposed to low and high $\mathrm{Al}$ concentrations. Different uppercase letter into species (E. platyphylla and $E$. grandis) and lowercase letter to Al concentrations (low and high) indicate significant differences from the Scott-Knott test $(\mathrm{P}<0.05)$. Columns represent the mean values from five repetitions, and bars represent the standard deviations.

\section{Discussion}

The increased $\mathrm{Al}$ contents in plants treated with high $\mathrm{Al}$ concentrations demonstrate that this element was absorbed and transported to leaves. Additionally, E. grandis presented a slight increase. Similar results in terms of minor $\mathrm{Al}$ accumulation in tolerant plants were verified by Noya et al. (2014).

Superoxide $\left(\mathrm{O}_{2}^{-}\right)$levels suffered increase in species exposed $\mathrm{Al}$, being it is a result of oxidative stress induced by the toxicity of this element, which promotes the reduction of $\mathrm{O}_{2}$ to $\mathrm{O}_{2}^{-}$and depending of the stress intensity may generate a subsequent generation of other ROS (Qin et al., 2010). $\mathrm{O}_{2}^{-}$is first ROS formed in cell, in this case the process was catalyzed by $\mathrm{Al}$, initiating a cascade of reactions to generate ROS secondary, such as $\mathrm{H}_{2} \mathrm{O}_{2}$ (Sharma et al., 2012). Wang and Yang (2005) also observed increase in $\mathrm{O}_{2}^{-}$levels of Cassia tora plants under $\mathrm{Al}$ application, corroborating with results of this study.

Increase of the SOD activity in plants treated with $\mathrm{Al}$ indicates $\mathrm{O}_{2}^{-}$overproduction, resulting from stress induced by the $\mathrm{Al}$ (Boscolo et al., 2003). The SOD acts as the first line of

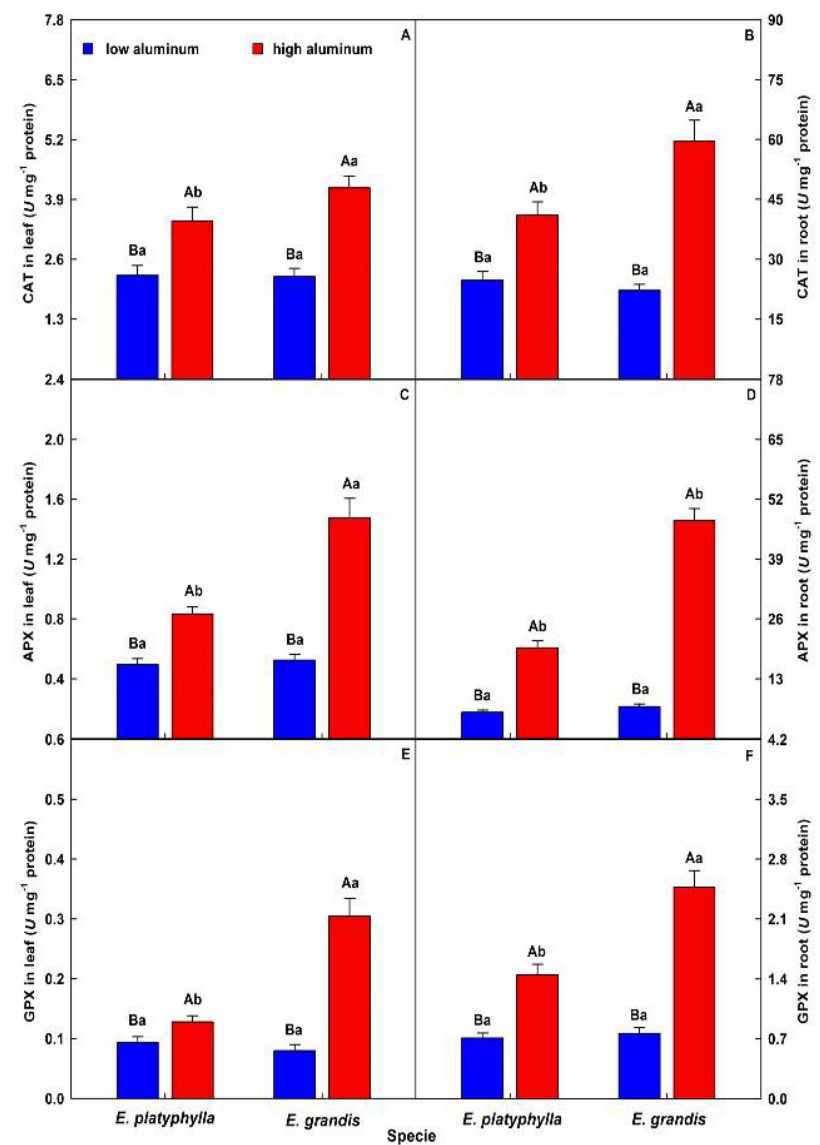

Fig. 4. Activities of catalase (A and B), ascorbate peroxidase (C and D), and peroxidase (E and F) in E. platyphylla and E. grandis exposed to low and high $\mathrm{Al}$ concentrations. Different uppercase letter into species (E. platyphylla and E. grandis) and lowercase letter to $\mathrm{Al}$ concentrations (low and high) indicate significant differences from the Scott-Knott test $(\mathrm{P}<0.05)$. Columns represent the mean values from five repetitions, and bars represent the standard deviations.

defense of the plants against oxidative stress, catalyzing the conversion of $\mathrm{O}_{2}^{-}$to $\mathrm{H}_{2} \mathrm{O}_{2}$ and $\mathrm{O}_{2}$ (El-Beltagi and Mohamed, 2013). Nogueirol et al. (2015), working with plants of the Solanum genus exposed to the $\mathrm{Al}$ application, found similar results to activity of this enzyme.

$\mathrm{H}_{2} \mathrm{O}_{2}$ levels were increased in two species exposed $\mathrm{Al}$, being related to the increase in SOD activity. SOD is an enzyme present in mitochondria and chloroplast membranes, the increase in your activity often results in overproduction of $\mathrm{H}_{2} \mathrm{O}_{2}$ (Schneider and Oliveira, 2004; Radic et al, 2010). Similar results on the increase in $\mathrm{H}_{2} \mathrm{O}_{2}$ levels were also reported by Yamamoto et al. (2015) evaluating Solanum lycopersicum plants exposed to Al.

The higher MDA values observed in two species exposed $\mathrm{Al}$ indicate increase in peroxidation of membrane lipids, being it explained by overproduction of reactive radicals, such as $\mathrm{O}_{2}$, which compromises the structure cell due to the stress oxidative (Guo et al., 2004). The $\mathrm{O}_{2}^{-}$, as well as other $\mathrm{ROS}$, cause damages 
112

to membrane structures due to lipid peroxidation and increasing the MDA content, which is considered the final product resulting of the membrane peroxidation (Guo et al., 2004; Tabaldi et al., 2007; Wu et al., 2014). Reyes-Diaz et al. (2010) studying Vaccinium corymbosum plants sensitive and exposed to $\mathrm{Al}$, reported similar results.

The increase in EL is related to oxidative damage caused by Al. In conditions of stress, the increase in the ROS amounts cause structural changes in the membrane, decreasing the ion exchange capacity and increasing ions release, resulting in the rupture of the membrane (Gill and Tuteja, 2010; Dawood et al., 2012). The EL is usually the last step observed due to the oxidative stress, also considered as a form to evaluate the state of permeability and membrane integrity and intensity of the cellular damages (Dawood et al., 2012; Langaro et al., 2014). Pereira et al. (2010) working with plant Cucumis sativus stressed with different $\mathrm{Al}$ concentrations described similar results.

The increase in GSSG is related to $\mathrm{H}_{2} \mathrm{O}_{2}$ accumulation in tissue caused by Al. During oxidative stress, the antioxidant defense mechanism, composed by enzymatic and non-enzymatic components, is driven aiming the detoxification process. One of the products formed in this process is the GSSG, considered an indicator of the physiological activity of intracellular defense against ROS, obtained from the GPX activity that uses $\mathrm{H}_{2} \mathrm{O}_{2}$ as substrate for the reaction (Apel and Hirt, 2004; Gill and Tuteja, 2010). Nguyen et al. (2005) working with Eucalyptus camaldulensis plants treated with $\mathrm{Al}$ reported similar results.

Increase in GSH levels in plants exposed to $\mathrm{Al}$ is related to increase of the activity of glutathione reductase (GR) (Sharma and Dubey, 2007). This enzyme plays a crucial role against oxidative stress, maintaining the GSH levels in adequate concentrations (Balakhinina and Borkowska, 2013). To produce $\mathrm{GSH}$, the GR enzyme reduces GSSG due NADPH consumption (Foyer and Noctor, 2000). Similar results on increase of this antioxidant compound were found by Xu et al. (2012) in Triticum aestivum plants cultivated in presence of Al.

Total GSH was increased after $\mathrm{Al}$ treatment, and it is considered as the combined effect of the accumulation observed in GSH and GSSG levels, also called non-enzymatic components of the redox glutathione cycle. This increase is related to the intensification of redox reactions of this cycle on stress conditions, aiming to reduce the production and accumulation of ROS. These reactions are mediated by the GR and GPX enzymes, which are catalytic agents of the reactions in the glutathione cycle (Noctor $e t$ al., 2002; Gill and Tuteja, 2010). Studies conducted by Yang et al. (2007) reported increases in total GSH values to Oryza sativa plants under Al application.

The increase in CAT activity in plants submitted to $\mathrm{Al}$ is related to higher concentrations of $\mathrm{H}_{2} \mathrm{O}_{2}$. The CAT is one of the enzymes linked to antioxidant machinery responsible to catalyse the $\mathrm{H}_{2} \mathrm{O}_{2}$ to $\mathrm{H}_{2} \mathrm{O}$ and $\mathrm{O}_{2}$. This action prevents the diffusion and accumulation of $\mathrm{H}_{2} \mathrm{O}_{2}$ in other cellular compartments, and making that this group remains in balanced concentrations within cells (Scandalios, 2005). Aftab et al. (2010) studying Artemisia annua plants exposed $\mathrm{Al}$ found similar results related to increase in activity of this enzyme.

The activity of APX enzyme increased in plants under Al exposition, and this response is related to overproduction of ascorbate (AsA). The AsA is an of the mains antioxidant compounds, acting on protection plants against oxidative damage under stress conditions (El-Beltagi and Mohamed,
2013). During the dismutation reaction of the $\mathrm{H}_{2} \mathrm{O}_{2}$ until $\mathrm{H}_{2} \mathrm{O}$ and $\mathrm{O}_{2}$, the APX uses the AsA as substrate to oxidize the monodehydroascorbate (MDHA) in end of the process (Apel and Hirt, 2004). Cucurbita pepo plants treated with $\mathrm{Al}$ also showed higher APX activity (Dipierro et al., 2005).

The increase in the GPX activity in plants after high $\mathrm{Al}$ is related due to intensification of oxidative stress generated by the concentration of this toxic metal, that it increase the ROS levels inside the cells. GPX is one of the main enzymes involved in the homeostatic control of the levels of ROS in the plant metabolism, and an increase in the activity of this enzyme corroborates the hypothesis linked to an efficient antioxidant defense system (Singh et al., 2012; Ribeiro et al., 2012) in $E$. grandis. Similar results were found by Prakash and Kumar (2014) evaluating Sorghun bicolor plants under influence of Al, agreeing with our results.

\section{Conclusion}

This study revealed that the E. platyphylla presented intense modifications on malondialdehyde and electrolyte leakage in leaf and root, being also detected increases to oxidized glutathione, reduced glutathione and total glutathione, In addition, $E$. platyphylla had strong accumulations linked to superoxide and hydrogen peroxide, while $E$. grandis were detected minor alterations to both tissues. In relation to superoxide dismutase, catalase, ascorbate peroxidase and peroxidase were showed similar behaviours, with higher activities in $E$. grandis, if compared to E. platyphylla. Therefore, is possible to conclude that E. grandis is more tolerant to aluminium due to minor production of reactive oxygen species and decreased alterations on stress indicators. Concomitantly, the antioxidant enzymes effectively contribute to reduce the oxidative stress generated in root and leaf of $E$. grandis exposed to high aluminium.

\section{Acknowledgments}

This research had financial support from Fundação Amazônia Paraense de Amparo à Pesquisa (FAPESPA/Brazil), Universidade Federal Rural da Amazônia (UFRA/Brazil) Conselho Nacional de Desenvolvimento Científico e Tecnológico ( $\mathrm{CNPq} / \mathrm{Brazil})$ to Lobato AKS, as well as Barros Junior UO and Lima MDR were supported by undergraduate scholarships also from Conselho Nacional de Desenvolvimento Científico e Tecnológico (CNPq/Brazil).

\section{References}

Achary VMM, Jena S, Panda KK, Panda BB (2008). Aluminium induced oxidative stress and DNA damage in root cells of Allium cepa $\mathrm{L}$. Ecotoxicology and Environmental Safery 70(2):300-310.

Aftab T, Khan MMA, Idrees M, Naeem M, Moinuddin (2010). Effects of aluminium exposures on growth, photosynthetic efficiency, lipid peroxidation, antioxidant enzymes and artemisinin content of Artemisia annua L.Journal of Phytology 2(8):23-37.

Alscher RG, Erturk N, Heath LS (2002). Role of superoxide dismutases (SODs) in controlling oxidative stress in plants. Journal of Experimental Botany 53(372):1331-1341. 
Apel K, Hirt H (2004). Reactive oxygen species: metabolism, oxidative stress, and signal transduction. Annual Review of Plant Biology 55:373-399.

Asada K (1999). The water-water cycle in chloroplasts: scavenging of active oxygens and dissipation of excesses photons. Annual Review of Plant Biology 50(1):601-639.

Asada K (2006). Production and scavenging of reactive oxygen species in chloroplasts and their functions. Plant Physiology 141(2):391-396.

Badawi GH, Yamauchi Y, Shimada E, Sasaki R, Kawano N, Tanaka K (2004). Enhanced tolerance to salt stress and water deficit by overexpressing superoxide dismutase in tobacco (Nicotiana tabacum) chloroplasts. Plant Science 166(4):919-928.

Balakhinina T, Borkowska A (2013). Effects of silicon on plant resistance to environmental stresses: a review. International Agrophysics 27(2):225232.

Barbosa MAM, Lobato AKS, Pereira TS, Viana GDM, Barbosa JRS, Coelho KNN, Sampaio LS, Santos Filho BG, Silveira JAG (2014). Photosynthesis-involvement in modulation of ascorbate and glutathione in Euterpe oleracea plants exposed to drought. Notulae Botanicae Horti Agrobotanici Cluj-Napoca 42(1):119-127.

Blokhina O, Virolainen E, Fagerstedt KV (2003). Antioxidants, oxidative damage and oxygen deprivation stress: a review. Annals of Botany 91(2):179-194.

Boscolo PRS, Menossi M, Jorge RA (2003). Aluminum-induced oxidative stress in maize. Phytochemistry 62(2):181-189.

Bradford MM (1976). A rapid and sensitive method for the quantification of microgram quantities of protein utilizing the principle of protein-dye binding. Analytical Biochemistry 72(1-2):248-254.

Cakmak I, Horst WJ (1991). Effect of aluminum on lipid peroxidation, superoxide Dismutase, catalase, and peroxidase activities in root tips of soybean (Glycinemax). Physiologia Plantarum 83(3):463-468.

Cakmak I, Marschner H (1992). Magnesium deficiency and high light intensity enhance activities of superoxide dismutase, ascorbate peroxidase, and glutathione reductase in bean leaves. Plant Physiology 98(4):1222-1227.

Chen L-S, Qi Y-P, Smith BR, Liu X-H (2010). Aluminum-induced decrease in $\mathrm{CO}_{2}$ assimilation in citrus seedlings is unaccompanied by decrease activities of key enzymes involved in $\mathrm{CO}_{2}$ assimilation. Tree Physiology 25(3):317-324.

Coscolin RBS, Broetto F, Marchese JA, Campohermoso MC, Paladini MV (2011). Effects of hydric deficiency on gas exchange parameters and metabolism of Eucalyptus grandis clones. Brazilian Journal of Plant Physiology 23(4):255-262.

Dawood M, Cao F, Jahangir MM, Zhang G, Wu F (2012). Alleviation of aluminum toxicity by hydrogen sulfide is related to elevated ATPase, and suppressed aluminum uptake and oxidative stress in barley. Journal of Hazardous Materials 209:121-128.

Delhaize E, Ryan PR (1995). Aluminum toxicity and tolerance in plants. Plant Physiology 107(2):315-321.

Dipierro N, MondelliD, Paciolla C, BrunettiG, Dipierro S(2005). Changes in the ascorbate system in the response of pumpkim (Cucurbita pepo L.) roots to aluminium stress. Journal of Plant Physiology 162(5):529-536.
Edreva A (2005). Generation and scavenging of reactive oxygen species in chloroplasts: a submolecular approach. Agriculture, Ecosystems and Environment 106(2):119-133.

El-Beltagi HS, Mohamed HI (2013). Reactive oxygen species, lipid peroxidation and antioxidative defense mechanism. Notulae Botanicae Horti AgrobotaniciCluj-Napoca41(1):4457.

Elstner EF, Heupel A (1976). Inhibition of nitrite formation from hydroxylammoniumchloride: a simple assay for superoxide dismutase. Analytical Biochemistry 70(2):616-620.

Foyer CH, Noctor G (2000). Oxygen processing in photosynthesis: regulation and signalling. New Phytologist 146:359-388.

Giannakoula A, Moustakas M, Syros T, Yupsanis T (2010). Aluminun stress induces up-regulation of an efficient antioxidant system in the Altolerant maize line but not in the Al-sensitive line. Environmental and Experimental Botany 67(3):487-494.

Giannopolitis CN, Ries SK (1977). Superoxide dismutase. I. Occurrence in higher plants. Plant Physiology 59(2):309-314.

Gill SS, Tuteja T (2010). Reactive oxygen species and antioxidant machinery in abiotic stress tolerance in crop plants. Plant Physiology and Biochemistry 48(12):909-930.

Gong M, Li YJ, Chen SZ (1998). Abscisic acid-induced thermotolerance in maize seedlings is mediated by calcium and associated with antioxidant systems. Journal of Plant Physiology 153(3):488-496.

Gratão PL, Polle A, Lea PJ, Azevedo RA (2005). Making the life of heavy metal-stressed plants a little easier. Functional Plant Biology 32(6):481494.

Griffith OW (1980). Determination of glutathione and glutathione disulfide using glutathione reductase and 2-vinylpyridine. Analytical Biochemistry 106(1):207-212.

Guo T,Zhang G, Zhou M, Wu F, Chen J (2004). Effects of aluminum and cadmium toxicity on growth and antioxidant enzyme activities of two barley genotypes with different $\mathrm{Al}$ resistence. Plant and Soil 258(1):241248.

Havir EA, Mchale NA (1987). Biochemical and developmental characterization of multiple forms of catalase in tabacco leaves. Plant Physiology 84(2):450-455.

Haynes RJ, Mokolobate MS (2001) Amelioration of Al toxicity and P deficiency in acid soils by additions of organic residues: a critical review of the phenomenon and the mechanisms involved. Nutrient Cycling in Agroecosystems 59(1):47-63.

Hoagland DR, Arnon DI (1950). The water culture method for growing plants without soil. California Agricultural Experiment Station, Berkeley.

Hoekenga OA, Vision JT, Shaff JE, Monforte AJ, Lee GP, Howell SH, Kochian LV (2003). Identification and characterization of aluminum tolerance loci in Arabidopsis (Landsberg erecta $\times$ Columbia) by quantitative trait locus mapping. A physiologically simple but genetically complex trait. Plant Physiology 132(2):936-948.

Langaro AC, Nohatto MA, Perboni LT, Tarouco CP, Agostinetto D (2014). Physiological changes in tomato crop due to simulated drift of herbicides. Revista Brasileira deHerbicidas 13(1):40-46. 
Leite DC, Cunha ACB, Bizani D (2011) Analysis of macro and micronutrients in a comparative study of inert soil to bioremediation processes. Revista de Ciências Ambientais 5(2):93-102.

Li C, Xu H, Xu J, Chun X, Ni D (2011) Effects of aluminium on ultrastructure and antioxidant activity in leaves of tea plants. Acta Physiologiae Plantarum 33(3):973-978.

Meriga B, Reddy BK, Rao KR, Reddy LA, Kishor PBK (2004). Aluminium-induced production of reactive radicals, lipid peroxidation and DNA damage in seedlings of rice (Oriza sativa). Journal of Plant Physiology 161(1):63-68.

Miller G, Suzuki N, Ciftci-Yilmaz, S, Mittler R (2010). Reactive oxygen species homeostasis and signalling during drought and salinity stresses. Plant, Cell andEnvironment 33(4):453-467.

Mittler R (2002). Oxidative stress, antioxidants and stress tolerance. Trends in PlantScience 7(9):405-410.

Moller IM (2001). Plant mitochondria and oxidative stress: Electron transport, NADPH turnover, and Metabolism of reactive oxygen species. Annu Rev Plant Physiol Plant Mol Biol 52(1):561-591.

Mukhopadyay M, Bantawa P, Das A, Sarkar B, Bera B, Ghosh P, Mondal TK (2012). Changes of growth, photosynthesis and alteration of leaf antioxidative defence system of tea [Camellia sinensis (L.) O. Kuntze] seedlings under aluminum stress. Biometals 25(6):1141-1154.

Nakano Y, Asada K (1981). Hydrogen peroxide is scavenged by ascorbate specific peroxidase in spinach chloroplasts. Plant and Cell Physiology 22(5):867-880.

Nguyen NT, Hiep ND, Fujita K (2005). Iron enhances aluminum-induced leaf necrosis and plant growth inhibition in Eucalyptus camaldulensis. Plant andSoil 277(1-2):139-152.

Noctor G, Gomez L, Vanacker H, Foyer CH (2002). Interactions between biosynthesis, compartmentation and transport in the control of glutathione homeostasis and signaling. Journal of Experimental Botany 53(372):283-1204.

Nogueirol RC, Monteiro FA, Gratão PL, Borgo L, Azevedo RA (2015). Tropical soils with high aluminum concentrations cause oxidative stress in two tomato genotypes. Environmental Monitoring and Assessment 187(3):73.

Nolla A, Anghinoni I (2004). Methods used to correction of the soil acidity in Brazil. Revista Ciências Exatase Naturais 6(1):97-111.

Noya AI, Ghulamahdi M, Sopandie D, Sutandi A, Melati M (2014). Interactive effects of aluminum and iron on several soybean genotypes grown in nutrient solution. Asian Journal of Plant Sciences 13(1):18-25.

Pereira ES, Silva ON, Filho AP, Felipe JP, Alves GAR, Lobato AKS (2015). Antioxidant enzymes efficiently control leaf and root cells damage in young Euterpe oleracea plants exposed to waterlogging. Indian Journal of Plant Physiology 20(3):213-219.

Pereira LB, Mazzanti CMA, Gonçalves JF, Cargnelutti D, Tabaldi LA, Becker AG, Calgaroto NS, Morsch VM, Schetinger MRC (2010). Aluminum-induced oxidative stress in cucumber. Plant Physiology and Biochemistry 48(8):683-689.

Pereira TS, Lobato AKS, Alves GAR, Ferreira RN, Silva ON, Martins Filho AP, Pereira ES, Sampaio LS (2014). Tolerance to waterlogging in young Euterpeoleracea plants. Photosynthetica 52(2):186-192.
Pitzschke A, Forzani C, Hirt H (2006). Reactive oxygen species signaling in plants. Antioxidants \& Redox Signaling8(9):1757-1764.

Prakash C, Kumar V (2014). Transcriptional and enzymatic regulation of antioxidant enzymes in aluminium Induced oxidative stress in sorghum roots and leaves. International Journal of Current Research 6(2):48584865.

Qin R, Jiao Y, Zhang S, Jiang W, Liu D (2010). Effects of aluminum on nucleoli in root tip cells and selected physiological and biochemical characters in Allium cepa var. agrogarum L. BMC Plant Biology 10(1):225.

Radic S, Babic M, Skobic D, Roje V, Pevalek-Kozlina B (2010). Ecotoxicological effects of aluminum and zinc on growth and antioxidants in Lemna minor L. Ecotoxicology and Environmental Safety 73(3):336-342.

Reyes-Díaz M, Inostroza-Blancheteau C, Millaleo R, Cruces E, WulffZottele C, Alberdi M, Mora ML (2010). Long-term aluminum exposure effects on physiological and biochemical features of highbush blueberry cultivars. Journal of the American Society for Horticultural Science 135(3):212-222.

Ribeiro C, Cambraia J, Peixoto PHP, Fonseca Júnior EM (2012). Antioxidant system response induced by aluminum in two rice cultivars. Brazilian Journal of Plant Physiology 24(2):107-116.

Scandalios JG (1993). Oxygen stress and superoxide dismutases. Plant Physiology 101(1):7-12.

Scandalios JG (2005). Oxidative stress: molecular perception and transduction of signals triggering antioxidant gene defenses. Brazilian Journal of Medical and Biological Research 38(7):995-1014.

Schneider CD, Oliveira AR (2004). Oxygen free radicals and exercise: mechanisms of synthesis and adaptation to the physical training. Revista Brasileira de Medicina doEsporte 10(4):308-313.

Sharma P, Dubey RS (2007). Involvement of oxidative stress and role of antioxidative defense system in growing rice seedlings exposed to toxic concentrations of aluminum. Plant Cell Reports 26(11):2027-2038.

Sharma P, Jha AB, Dubey RS, Pessarakli M (2012). Reactive oxygen species, oxidative damage, and antioxidative defense mechanism in plants under stressful conditions. Journal of Botany 2012:1-27.

Singh S, Verma A, Dubey VK (2012). Effectivity of anti-oxidative enzymatic system on diminishing the oxidative stress induced by aluminium in chickpea (Cicer arietinum L.) seedlings. Brazilian Journal of Plant Physiology 24(1):47-54.

Steel RGD, Torrie JH, Dickey DA (2006). Principles and procedures of statistics: a biometrical approach, 3rd edn. Academic Internet Publishers, Moorpark.

Tabaldi LA, Nicoloso FT, Castro GY, Cargnelutti D, Gonçalves JF, Rauber R, Skrebsky EC, Schetinger MRC, Morsch VM, Bisognin DA (2007). Physiological and oxidative stress responses of four potato clones to aluminum in nutrient solution. Brazilian Journal of Plant Physiology 19(3):211-222.

Velikova V, Yordanov I, Edreva A (2000). Oxidative stress and some antioxidant system in acid rain treated bean plants: protective role of exogenous polyamines. Plant Science 151(1):59-66. 
Wang CQ, Liu TL, Xu HJ (2011). Ascorbate - Glutathione metabolism during PEG-Induced water deficit in Trifolium repens. Russ J Plant Physiol 58(4):597-602.

Wang Y-S, Yang Z-M (2005). Nitric oxide reduces aluminum toxicity by preventing oxidative stress in the roots of Cassia tora L. Plant and Cell Physiology46(12):1915-1923.

Wu D, Shen H, Yokawa K, Baluska F (2014). Alleviation of aluminuminduced cell rigidity by overexpression of OsPIN2 in rice roots. Journal of Experimental Botany 65(18):5305-5315.

Wu QS, Xia RX, Zou YN (2006). Reactive oxygen metabolism in mycorrhizal and non-mycorrhizal citrus (Poncirus trifoliata) seedlings subjected to water stress. Journal of Plant Physiology 163(11):11011110.

Xu FJ, Li G, Jin CW, Liu WJ, Zhang SS, Zhang YS, Lin XY (2012). Aluminum-induced changes in reactive oxygen species accumulation, lipid peroxidation and antioxidant capacity in wheat root tips. Biologia Plantarum 56(1):89-96.
Yamamoto T, Okuda H, Nozawa R, Furukawa J, Miura K (2015). Enhancement of cold tolerance promotes resistance to aluminum stress. International Journal of Plant Biology \& Research 3(2):1032.

Yamamoto Y, Kobayashi Y, Devi SR, Rikiishi S, Matsumoto H (2002). Aluminum toxicity is associated with mitochondrial dysfunction and the production of reactive oxygen species in plant cells. Plant Physiology 128(1):63-72.

Yamamoto Y, Kobayashi Y, Devi SR, Rikiishi S, Matsumoto H (2003). Oxidative stress triggered by aluminum in plants roots. Plant and Soil 255:239-243.

YangQ, Wang Y,ZhangJ,Shi W, Qian C, PengX (2007).Identification of aluminum-responsive proteins in rice roots by a proteomic approach: cysteine synthase as a key player in $\mathrm{Al}$ response. Proteomics 7(5):737749.

Zhu X, Fengbin S, Hongwen X (2010). Influence of arbuscular mycorrhiza on lipid peroxidation and antioxidant enzyme activity of maize plants under temperature stress. Mycorrhiza 20(5):325-332. 